\title{
Clinical use of plerixafor in combination with granulocyte-colony stimulating factor in hematopoietic stem cell transplantation
}

This article was published in the following Dove Press journal:

Transplant Research and Risk Management

10 May 2010

Number of times this article has been viewed

\author{
Cedar J Fowler' \\ Richard T Maziarz ${ }^{2}$ \\ 'Laboratory of Clinical Infectious \\ Diseases - NIAID, National Institutes \\ of Health, Bethesda, MD, USA; \\ ${ }^{2}$ Adult Blood and Marrow Stem \\ Cell Transplant Program, Oregon \\ Health and Science University, \\ Portland, OR, USA
}

\begin{abstract}
Plerixafor is a CXC4:CXCL12 antagonist that has an expanding role in the stem cell mobilization phase of the hematopoietic stem cell transplant procedure. The drug is currently licensed by the FDA to be used in combination with granulocyte colony stimulating factor (G-CSF) to mobilize hematopoietic stem cells into the peripheral blood for collection and subsequent autologous transplantations in patients with non-Hodgkin's lymphoma and multiple myeloma. Plerixafor is particularly useful in patients who have been heavily pretreated or as effective therapy for frontline salvage of poor peripheral blood stem cells mobilizers. In conjunction with G-CSF, plerixafor can be successful in decreasing the number of apheresis days and therefore the associated additional risks and cost of more apheresis procedures. Patients taking plerixafor, when compared to the side effect profile of G-CSF alone, do not report significantly more side effects.
\end{abstract}

Keywords: plerixafor, AMD3100, autologous stem cell mobilization, non-Hodgkin's lymphoma, multiple myeloma, CXCR4, CXCL12

\section{The role of plerixafor in moblization of patients with multiple myeloma or non-Hodgkin's lymphomas}

The goal of a hematopoietic stem cell transplant is to improve the progression free and/or overall survival in patients with hematologic malignancies. A critical first step is to mobilize and collect sufficient number of stem cells capable of prompt and durable hematopoietic reconstitution. Mobilized peripheral blood stem cells (PBSCs) have progressively replaced bone marrow, used since the 1960s, as the preferred source of stem cells used for the reconstitution of hematopoiesis. ${ }^{1,2}$ This shift to PBSC is based on the demonstration of improved clinical outcomes; including faster engraftment, less invasive collection, and reduced morbidity. ${ }^{3,4} \mathrm{~A}$ current target goal for discharge after hosptialzation include standard engraftment parameters of: 1) absolute neutrophil count greater than $0.5 \times 10^{9} / \mathrm{L}$ in 10 to 12 days and 2) platelet count greater than $20 \times 10^{9} / \mathrm{L}$ in 15 to 30 days. To achieve these targets, most transplant centers use a minimal mobilization requirement for a successful engraftment at approximately $2.0 \times 10^{6} \mathrm{CD} 34^{+}$cells $/ \mathrm{kg}$ based on actual body weight. Optimal cell dose needed to enhance the likelihood for a successful transplant with long-term complete sustained hematopoietic engraftment has been proposed as greater than $5 \times 10^{6} \mathrm{CD} 34^{+}$cells $/ \mathrm{kg} .^{5,6}$ Failure to transplant sufficient number of hematopoietic stem cells can lead to delayed engraftment, ongoing transfusion dependence, graft failure, and possibly death.

According to the Center for International Blood and Marrow Transplant Research (CIBMTR), more than 18,000 allogeneic and autologous transplant procedures were 
performed in the US in 2006 with continued annual increases in that number projected. ${ }^{7}$ Autologous hematopoietic stem cell transplant (ASCT) is the preferential therapy for many of these hematologic malignancies, particularly for multiple myeloma (MM) and non-Hodgkin's lymphoma (NHL). MM and NHL accounted for $72 \%$ of the more than 10,000 ASCT performed in North America in 2005. ${ }^{8}$ During that year, MM accounted for $42 \%$ and currently is the most common indication for high-dose chemotherapy and ASCT. ${ }^{9}$ The combination of high-dose chemotherapy with ASCT continues to be recommended for patients with newly diagnosed MM, within the first year of diagnosis, and is preferred as an early treatment rather than as a salvage treatment for relapsed, refractory disease. ${ }^{10}$ This ongoing recognition of the importance of ASCT for myeloma is highlighted by the novel Blood and Marrow Transplant (BMT) Clinical Trials Network (CTN) (BMT CTN) and intergroup clinical trial that opened for accrual in the winter of 2009 in which all patients under age 70 with responding myeloma within the first year of treatment will proceed to transplantation and are then randomized to one of three consolidation and maintenance arms. ${ }^{11}$

NHL accounted for $30 \%$ of the ASCT in North America in $2005,{ }^{8}$ but more importantly, this malignancy has had constant increase in numbers over the past 3 decades and has now become the number five killer of Americans from cancerous causes. Thus, the expectation is that the need for hematopoietic stem cell transplantation (HSCT) will continually increase based on the increase in this disease. HSCT is recommended in the setting of first chemotherapy-sensitive relapse for diffuse large B. cell lymphoma, first complete remission (CR) in high-intermediate to high-risk patients, based on international prognostic index (IPI), and for many other clinical scenarios in NHL. In addition, peripheral ASCT is preferentially preferred over BMT or allogeneic transplant. ${ }^{12,13}$

While the Food and Drug Administration (FDA) has approved both granulocyte colony stimulating factor (G-CSF; filgrastim) and granulocyte-macrophage colony stimulating factor (GM-CSF; sargramostim) for the mobilization of autologous stem cells, the predominant method of mobilizing CD34 ${ }^{+}$ stem cells into the peripheral blood in either the autologous or allogeneic setting uses G-CSF. GM-CSF mobilizes fewer $\mathrm{CD}^{+}{ }^{+}$cells than G-CSF and has been incorporated into combined mobilization strategies, although whether this is true synergy or whether the same augmented collection could be achieved by dose escalation of G-CSF alone, remains unclear. ${ }^{14} \mathrm{G}-\mathrm{CSF}$ based PBSC mobilization can be performed in combination with chemotherapy or with 4 to 6 days of daily treatment of G-CSF, with previous studies demonstrating a dose response of G-CSF alone up to levels of $32 \mu \mathrm{g} / \mathrm{kg}$. The different types of mobilization agents have their own kinetics with respect to $\mathrm{CD}_{3} 4^{+}$stem cells mobilization from the bone marrow and have unique dosing regimens. G-CSF and chemotherapy was the main option and requires 1 to 3 weeks for mobilization, as a consequence of awaiting hematological recovery of the bone marrow from the insult. Studies combining G-CSF with chemotherapy agents did not show a constant difference in overall survival or progression-free survival when compared to G-CSF alone. ${ }^{15}$ At the other end of the spectrum are the more recent discoveries of receptor/signaling pathway antagonists where enhanced and effective mobilization of CD34 ${ }^{+}$stem cells can occur in a matter of hours.

Finally, it is important to note that despite efforts to standardize approaches to maximize cell collection in all patients, approximately $25 \%$ of individual patients undergoing mobilization have been proven to be 'poor mobilizers', collecting less than $2.0 \times 10^{6}$ total CD34+ ${ }^{+}$stem cells $/ \mathrm{kg} .{ }^{16,17}$ The factors that can lead to insufficient PBSC mobilization are multifactorial and include: individual variation in responsiveness to G-CSF, ${ }^{18,19}$ degree and type of pre-treatment with primary and salvage regimens, ${ }^{20,21}$ specific type of hematopoietic malignancy, ${ }^{20,22,23}$ and presence or absence of underlying marrow fibrosis. Patients who fail initial mobilization regimens are also more likely to fail remobilization. ${ }^{24}$ To create transplant opportunities, alternative mobilization approaches for primary and salvage efforts have been explored, recognizing that a failed mobilization for an HSCT patient would either require no longer pursuing transplant or utilizing an allogeneic donor, with its increased risks of non-relapse mortality. ${ }^{7}$ Such options included recombinant human stem-cell factor which failed to gain FDA approval for US use, but has been developed as a clinical product in other countries, including Canada and Australia, ${ }^{25}$ development of novel mobilization molecules such as pixy 321 (G-CSF/IL3), and combining G-CSF and GM-CSF. Another very exciting development has been the evaluation of plerixafor as a stem cell mobilization agent that led to its recent FDA approval in December 2008 for patients with MM and NHL. In this review, the clinical application of plerixafor primarily in MM and NHL patients will be discussed in the overall context of the transplant setting.

\section{CXCR:CXCL 12 axis and initial studies of plerixafor}

Plerixafor (Mozobil ${ }^{\circledR}$; Genzyme Corp; previously known as AMD3100, JM 3100, SDZ SID 791) was initially tested in the mid 1990s by Anormed, Inc. as a potent inhibitor of particular 
HIV strains. ${ }^{26,27}$ At first, the mechanism of action was unclear but further discovery proved that plerixafor selectively inhibits the CXCR4 co-receptor used by T-lymphotropic X4 strains of HIV during viral entry of HIV replication. During the initial trials, plerixafor was incidentally noted to elicit significant transient leukocytosis in both healthy and HIV-infected volunteers. The HIV trials were not successful in demonstrating significant viral RNA reduction and were only capable of demonstrating significant reduction in HIV RNA in a single patient. The patient was confirmed to be infected with only a CXCR4 virus and given the highest tested dose $(160 \mu \mathrm{g} / \mathrm{kg} / \mathrm{h})$ of plerixafor. The observation of transient leukocytosis has led to exploration of plerixafor's role in mobilization of hematopoietic stem and progenitor cells (HSPC). ${ }^{28-31}$

The CXCR4 chemokine receptor and its ligand CXCL 12 (also known as stromal cell-derived factor 1, SDF-1) is involved in cell homing during embryogenesis/organogenesis and functions; and is integral to maintaining bone marrow homeostasis with its ultimate role in repopulating the hematopoietic and immunological niche. ${ }^{32,33}$ The CXCR4 receptor, a seven transmembrane G-protein-coupled chemokine receptor of the rhodopsin family, is the primary functional chemokine receptor expressed by HSPC. ${ }^{34}$ CXCR 4 receptor is also expressed on a wide variety of other tissues including B cells, monocytes, majority of T-lymphoctyes, endothelial cells, and epithelial cells. ${ }^{35}$ The ligand, CXCL 12, was originally characterized as a pre-B cell growth factor derived from bone marrow stromal cells. Further research has shown that CXCL 12 is produced by mesenchymal stromal cells within the bone marrow niche and in other tissues, including the liver, lungs, and the lymphatics. ${ }^{36-38}$

In adult hematopoiesis the expression of CXCR4 receptor and the responsiveness to CXCL 12 changes during differentiation of cells within the lymphoid ${ }^{39}$ and myeloid ${ }^{40,41}$ lineages. The interaction between CXCR4 chemokine receptor and the CXCL 12 ligand is a key regulator of the migration of the $\mathrm{HSPCs}^{42}$ in the bone marrow microenvironment and is also involved in tumor progression in both hematopoietic and non-hematopoietic cancers. ${ }^{43-45}$ Therefore the inhibition of the CXCR4:CXCL 12 axis is hypothesized as an attractive target for the mobilization of HSPC as well as for targeting leukemic stem cells. ${ }^{46,47}$

\section{Review of pharmacology, mode of action, pharmacokinetics of plerixafor} Plerixafor is a reversible antagonist of CXCR4 receptor. Plerixafor is a white to off white hygroscopic crystalline solid with a molecular weight of $502.79 \mathrm{~g} / \mathrm{mol}$ (for the free base). Plerixafor is considered a bicyclam, consisting of two cyclam rings coupled through a 1,4-phenylenebis(methylene) moiety (proper chemical name: 1,1'-[1,4-phenylenebis (methylene)]-bis-1,4,8,11-tetraazacylotradecane). It is water soluble and exists at $\mathrm{a}^{+} 4$ protonated state at physiological pH (Figure 1).

Bioavailability is $87 \%$ after subcutaneous injection. Two phase I trials examined pharmacokinetics in 29 healthy volunteers. The volunteers received subcutaneous injections of 40 , $80,160,240$ or $320 \mu \mathrm{g} / \mathrm{kg}$. The data demonstrate a two compartment model with first-order absorption characteristics and an indirect effect model for the release of bone marrow $\mathrm{CD} 4^{+}$cells to the peripheral blood. Clearance of plerixafor is $5.17 \pm 0.49 \mathrm{~L} / \mathrm{h}$ and volume of distribution is $16.9 \pm 3.79 \mathrm{~L} / \mathrm{h}$. The maximal effect occurs at $12.6 \pm 4.89$ hours and $50 \%$ of maximum response occurs at $5.37 \pm 1.31$ hours. ${ }^{48}$

Intravenous (IV) infusion route examined in 12 volunteers at a dose of $10,20,40,80 \mu \mathrm{g} / \mathrm{kg}$ demonstrated similar white blood cell (WBC) count peaking as subcutaneous dosing. WBC peaked at 6 hours post IV administration with a similar WBC increase when compared to higher doses used during subcutaneous administration. The $\mathrm{C}_{\max }$ for IV dosing was 515 (range, 470-521) ng/mL and the AUC was 1044 (range, 980-1403) ng.h/mL. Oral dosing demonstrated no appreciated plasma levels up to $160 \mu \mathrm{g} / \mathrm{kg} .{ }^{49}$

Plerixafor is not a substrate, inhibitor, or inducer of P450 isozymes. As a selective antagonist of CXCR4, plerixafor also demonstrates no cross reactivity with other chemokine receptors, CXCR1-3 or CCR1-9. While plerixafor is capable of binding CXCR4 receptor, it does

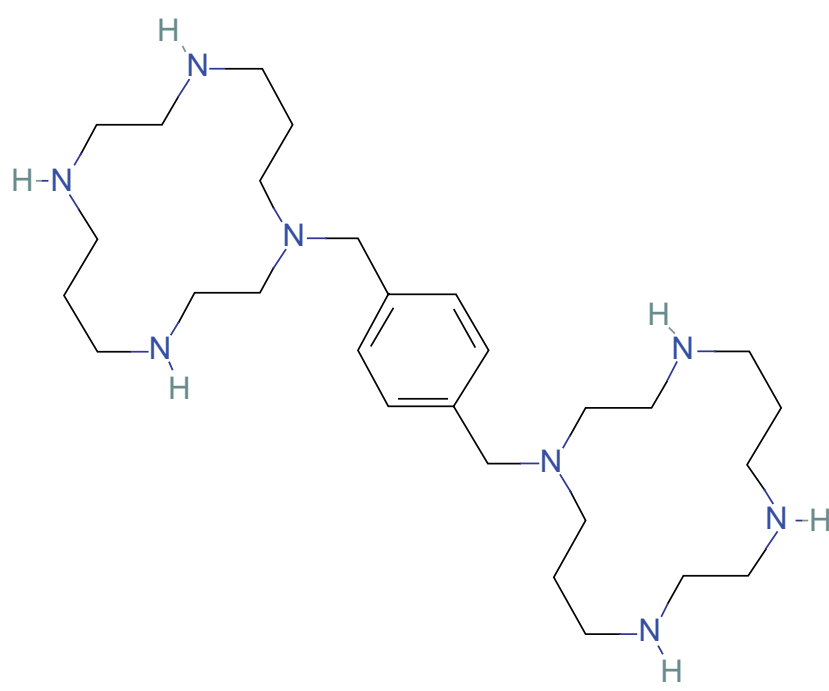

Figure I Chemical structure of plerixafor. 
not elicit intracellular calcium fluxes, induce chemotaxis, or trigger CXCR4 internalization. ${ }^{50}$ The natural ligand of CXCR4, CXCL 12, is also cross reactive with CXCR7; however plerixafor is not. ${ }^{51}$ The current model describing the interaction between CXCL 12 and CXCR4 proposes that CXCL 12 associates with cellular gylcosaminogylcans via its carboxy terminus leaving the N-terminus of CXCL 12 free to bind the CXCR4 receptor expressed by hematopoietic cells and or non-hematopoietic cells (during remodeling events). ${ }^{52,53}$ Plerixafor is capable of inhibiting CXCL 12 binding to CXCR4 with a $\mathrm{K}_{\mathrm{d}}$ of $651 \pm 37 \mathrm{nM}$. The data show that plerixafor is a tight binding, slowly reversible inhibitor of CXCR4. ${ }^{54}$

The current 2008 FDA approval of plerixafor is in combination with G-CSF at a dose of $10 \mu \mathrm{g} / \mathrm{kg}$ used to mobilize hematopoietic stem cells into the peripheral blood for collection and subsequent autologous transplantations in patients with NHL and MM. Administration of plerixafor should begin after 4 days of daily treatment with G-CSF and 11 hours prior to apheresis. It is supplied as a single use vial containing $1.2 \mathrm{~mL}$ of $20 \mathrm{mg} / \mathrm{mL}$ solution. Plerixafor administration can continue for 4 consecutive days. Dosing of plerixafor is $0.24 \mathrm{mg} / \mathrm{kg}$ of actual body weight and has been verified for patients up to $175 \%$ of ideal body weight. The total daily dosage should not exceed $40 \mathrm{mg} /$ day. Patients with moderate to severe renal impairment $\left(\mathrm{CL}_{50} \leq 50 \mathrm{~mL} / \mathrm{min}\right)$ should receive a dose reduction of one-third and a maximum daily dosage of $27 \mathrm{mg}$ /day. Approximately $70 \%$ of a daily dose is excreted unchanged via kidneys in healthy volunteers in the first 24 hours. The plasma half-life is 3 to 5 hours. In 543 patients reported for drug approval, the median exposure to plerixafor is 2 days (range 1 to 7 days). Used as a single agent, peak mobilization of CD34+ cells is between 6 and 9 hours post administration. When G-CSF is added, a sustained elevation in the peripheral blood $\mathrm{CD} 34^{+}$count occurs from 4 to 18 hours, with the peak CD34+ count between 10 and 14 hours. ${ }^{55}$

There is some evidence implying plerixafor may mobilize leukemic cells during mobilization and therefore should not be used in patients with leukemia. ${ }^{56,57}$ Other contraindications include leukocytosis and thrombocytopenia, although these are considerations, as these are standard sequelae of G-CSF mobilization with or without chemotherapy. The current recommendation is to examine any patient who reports upper left quadrant pain, shoulder pain, or scapular pain for splenic integrity. This precaution is based on murine studies that demonstrated splenic enlargement. The murine studies did involve continual plerixafor administration lasting
2 to 4 weeks at $4 \times$ higher dosage than that given during clinical trials. The concern about the spleen and its potential for rupture with prolonged dosing arises from reports of splenic rupture in patients undergoing stem cell mobilization with G-CSF alone. ${ }^{58}$

The most common adverse events, reported in $>10 \%$ of people taking plerixafor with G-CSF, regardless of relatedness, are diarrhea, nausea, fatigue, injection site reactions, headache, arthralgia, dizziness, and vomiting. The adverse events throughout the clinical trials have been similar to those seen in the early trials, consisting of mild complaints involving gastrointestinal complaints, headaches, dry mouth, and injection site reaction. ${ }^{49,59}$

\section{Preclinical efficacy studies of plerixafor}

Plerixafor is capable of inducing HSPC mobilization in multiple species due to the conserved function of the CXCR4: CXCL 12 axis. Murine studies demonstrated that plerixafor can rapidly, and in synergy with G-CSF, mobilize human and murine HSPCs. Murine HSPCs mobilized with plerixafor were capable of long term engraftment in severe combined immunodeficiency (SCID) mice. ${ }^{31}$ The study also showed that the addition of plerixafor to G-CSF leads to enhanced numbers of HSPCs. The mobilized cells express a phenotype characteristic of highly engrafting murine HSPCs. ${ }^{28,48,60}$

Canine studies demonstrated that plerixafor treatment alone could lead to durable grafts. Dogs were treated with 920 cGY total body irradiation and transplanted with either autologous plerixafor mobilized PBSCs or plerixafor mobilized PBSCs from antigen identical littermate. Autologous and allogeneic transplanted canines had normal marrow function at 1 year and chimerism levels were $97 \%$ to $100 \% .{ }^{61}$ Plerixafor has also been studied as single agent for mobilization of stem cells in a rhesus macaque model. The study demonstrated that plerixafor was capable of mobilizing a long-term repopulating population of cells that had intrinsic differences from the population mobilized with G-CSF. There appeared to be increase in expression of cell-surface markers implicated in retention and homing in the plerixafor mobilized $\mathrm{CD}^{+} 4^{+}$cells. $^{62}$

Plerixafor with or without G-CSF gene expression data has also been examined in the rhesus macaque. The data confirm previous studies that suggest that the composition of the stem cells depends on the mobilization protocol. The study demonstrated that plerixafor based $\mathrm{CD} 34^{+}$cells include more $\mathrm{B}$, T, and mast cell precursors while G-CSF based protocols have more neutrophil and mononuclear phagocytes. ${ }^{63}$ 
Table I Summary of trials involving plerixafor

\begin{tabular}{|c|c|c|c|c|c|c|c|}
\hline Study & $\begin{array}{l}\text { Study design } \\
\text { features }\end{array}$ & Disease & Enrollment & $\begin{array}{l}\text { Plerixafor } \\
\mu g / \mathrm{kg}\end{array}$ & $\begin{array}{l}\text { Administration } \\
\text { of drug }\end{array}$ & Outcome & Study \\
\hline Phase I & $\begin{array}{l}\text { Open label: IV, SQ, } \\
\text { and oral dosing }\end{array}$ & $\begin{array}{l}\text { Healthy } \\
\text { volunteers }\end{array}$ & 12 & $10,20,40,80$ & Plerixafor & $\begin{array}{l}\text { SQ and IV } \\
\text { dosing yields } \\
\text { in vitro } \\
\text { antiretroviral } \\
\text { concentration }\end{array}$ & Hendrix et a ${ }^{49}$ \\
\hline Phase I & $\begin{array}{l}\text { SQ: serial } \\
\text { administration }\end{array}$ & $\begin{array}{l}\text { Healthy } \\
\text { volunteers }\end{array}$ & 26 & 80,240 & Plerixafor & $\begin{array}{l}\text { Generalized } \\
\text { leukocytosis, } \\
\text { mild toxicities, } \\
\text { increase } \\
\text { CD34+ count }\end{array}$ & Liles et $\mathrm{al}^{64}$ \\
\hline Phase I & $\begin{array}{l}3 \text { cohorts: single } \\
\text { dose admin } \\
\text { w/ and w/out } \\
\text { G-CSF }\end{array}$ & $\begin{array}{l}\text { Healthy } \\
\text { volunteers }\end{array}$ & 31 & 160,240 & $\begin{array}{l}\text { Plerixafor + } \\
\text { G-CSF }\end{array}$ & $\begin{array}{l}\text { Increase in CD } 34^{+} \\
\text {count, indicate } \\
\text { plerixafor can } \\
\text { be used alone } \\
\text { or in conjunction }\end{array}$ & Liles et $\mathrm{al}^{65}$ \\
\hline Phase I & $\begin{array}{l}\text { Open label: single } \\
\text { dose SQ }\end{array}$ & $\begin{array}{l}\text { Healthy } \\
\text { volunteers }\end{array}$ & 29 & $\begin{array}{l}40,80,160 \\
240,320\end{array}$ & Plerixafor & $\begin{array}{l}\text { Pharmacokinetic- } \\
\text { pharmacodynamic } \\
\text { model: } \\
\text { 2-compartment } \\
\text { model }\end{array}$ & Lack et $\mathrm{al}^{48}$ \\
\hline Phase I & $\begin{array}{l}\text { Open label: single } \\
\text { center, single dose }\end{array}$ & $\begin{array}{l}\text { Healthy } \\
\text { volunteers }\end{array}$ & 32 & $\begin{array}{l}40,80,160 \\
240,320\end{array}$ & Plerixafor & $\begin{array}{l}\text { Generalized } \\
\text { leukocytosis, well } \\
\text { tolerated }\end{array}$ & Hübel et $\mathrm{a}^{59}$ \\
\hline Phase I & $\begin{array}{l}\text { Open label, } \\
\text { uncontrolled }\end{array}$ & $\mathrm{MM}, \mathrm{NHL}$ & 13 & 160,240 & Plerixafor single dose & $\begin{array}{l}\text { Increase in CD34 } \\
\text { count over } \\
\text { baseline }\end{array}$ & Devine et $\mathrm{a}^{66}$ \\
\hline Phase II & $\begin{array}{l}\text { Randomized, } \\
\text { sequential } \\
\text { apheresis } \\
\text { with } A+G / G\end{array}$ & $\mathrm{MM}, \mathrm{NHL}$ & 25 & 160,240 & $\begin{array}{l}\text { Plerixafor + } \\
\text { G-CSF: G-CSF }\end{array}$ & $\begin{array}{l}\text { apheresis } \\
>5 \times 10^{6} \mathrm{CD} 34 \\
\text { count, } 90 \% \text { success, } \\
\text { fewer apheresis } \\
\text { with plerixafor }+ \\
\text { G-CSF }\end{array}$ & Flomenberg et a $\mathrm{l}^{67}$ \\
\hline Phase II & $\begin{array}{l}4 \text { cohorts, } \\
\text { sequential design }\end{array}$ & $\mathrm{MM}, \mathrm{NHL}$ & 40 & 160 & $\begin{array}{l}\text { Chemotherapy, G-CSF, } \\
\text { plerixafor on day I or } \\
\text { day of apheresis }\end{array}$ & $\begin{array}{l}\text { Safety of } \\
\text { plerixafor } \\
\text { with chemotherapy }\end{array}$ & Dugan et $\mathrm{al}^{72}$ \\
\hline Phase II & Open label & $\mathrm{MM}, \mathrm{NHL}$ & 35 & 240 & Plerixafor + G-CSF & $\begin{array}{l}\text { No increase } \\
\text { in tumor cell } \\
\text { mobilization }\end{array}$ & Fruehauf et $\mathrm{al}^{70}$ \\
\hline Phase II & $\begin{array}{l}\text { Open label, } \\
\text { sequential testing }\end{array}$ & $\mathrm{MM}, \mathrm{NHL}$ & 15 & 240 & $\begin{array}{l}\text { G-CSF: plerixafor + } \\
\text { G-CSF }\end{array}$ & $\begin{array}{l}\text { Increase in } \\
\text { primitive } \\
\text { CD } 34^{+} \text {cells } \\
\text { with plerixafor }\end{array}$ & Fruehauf et $\mathrm{al}^{71}$ \\
\hline Phase II & $\begin{array}{l}\text { Open label, } \\
\text { heavily pretreated }\end{array}$ & $\mathrm{MM}, \mathrm{NHL}$ & 49 & 240 & $\begin{array}{l}\text { Plerixafor + } \\
\text { G-CSF }\end{array}$ & $\begin{array}{l}\text { Plerixafor } \\
\text { successful in heavily } \\
\text { pretreated patients }\end{array}$ & Stiff et al ${ }^{69}$ \\
\hline Phase II & Open label & MM & 20 & 240 & $\begin{array}{l}\text { Plerixafor + } \\
\text { G-CSF }\end{array}$ & $\begin{array}{l}12 \text { of } 17 \\
\text { durable grafts at } \\
12 \text { months }\end{array}$ & Tricot et $\mathrm{al}^{74}$ \\
\hline Phase III & $\begin{array}{l}\text { RCT: placebo, } \\
\text { double blind }\end{array}$ & MM & 302 & 240 & $\begin{array}{l}\text { Plerixafor + } \\
\text { G-CSF: G-CSF }\end{array}$ & $\begin{array}{l}\text { Increased } \\
\text { probability of } \\
\text { collecting } \\
6 \times 10^{6} \mathrm{CD} 34 \\
\text { count in } 2 \text { or } \\
\text { less apheresis }\end{array}$ & Dipersio et $\mathrm{a}^{89}$ \\
\hline
\end{tabular}

(Continued) 
Table I (Continued)

\begin{tabular}{|c|c|c|c|c|c|c|c|}
\hline Study & $\begin{array}{l}\text { Study design } \\
\text { features }\end{array}$ & Disease & Enrollment & $\begin{array}{l}\text { Plerixafor } \\
\mu g / k g\end{array}$ & $\begin{array}{l}\text { Administration } \\
\text { of drug }\end{array}$ & Outcome & Study \\
\hline Phase III & $\begin{array}{l}\text { RCT: placebo, } \\
\text { double blind }\end{array}$ & $\mathrm{NHL}$ & 298 & 240 & $\begin{array}{l}\text { Plerixafor }+ \\
\text { G-CSF: G-CSF }\end{array}$ & $\begin{array}{l}\text { Increased } \\
\text { probablity of } \\
\text { collecting } \\
6 \times 10^{6} \text { in } \\
2 \text { or less apheresis }\end{array}$ & Dipersio et $\mathrm{al}^{88}$ \\
\hline CUP & $\begin{array}{l}\text { Open label, } \\
\text { uncontrolled }\end{array}$ & $\begin{array}{l}\text { MM, HD, } \\
\text { NHL, } \\
\text { AILD }\end{array}$ & 20 & 240 & $\begin{array}{l}\text { Plerixafor + } \\
\text { G-CSF }\end{array}$ & $\begin{array}{l}\text { I7 of } 20 \text { successful } \\
\text { mobilizations }\end{array}$ & Fowler et $\mathrm{a}^{73}$ \\
\hline CUP & $\begin{array}{l}\text { Open label, } \\
\text { uncontrolled }\end{array}$ & $\begin{array}{l}\text { MM, HD, } \\
\text { NHL }\end{array}$ & 115 & 240 & $\begin{array}{l}\text { Plerixafor + } \\
\text { G-CSF }\end{array}$ & $\begin{array}{l}60 \%-75 \% \\
\text { successful } \\
\text { mobilization } \\
\text { rate }\end{array}$ & Calandra et $\mathrm{al}^{78}$ \\
\hline
\end{tabular}

Abbreviations: A + G, plerixafor + G-CSF; AILD, angioimmunoblastic lymphoma; CUP, compassionate use protocol; G-CSF, granulocyte colony stimulating factor; IV, intravenous; SQ, subcutaneous; MM, multiple myeloma; NHL, non-Hodgkin's lymphoma; RCT, randomized controlled trial. HV, healthy volunteer; Hd, Hodgkin's lymphoma.

\section{Plerixafor clinical trials and analysis}

There are 32 registered clinical trials currently listed in clinicaltrials.gov ( 3 withdrawn or terminated prior to enrollment) involving plerixafor and hematological malignancies at the time of preparation of this manuscript, confirming the interest in this novel compound. ${ }^{64}$ The trials discussed in this review are listed in Table 1.

\section{Phase I}

Following the phase I HIV trials, further phase I trials demonstrated consistent leukocytosis and mobilization of $\mathrm{CD} 4^{+}$stem cells following infusion of plerixafor in 12 healthy volunteers ${ }^{51}$ and 32 healthy volunteers. ${ }^{59}$ The effect was confirmed linear over a large range of doses and schedules. ${ }^{48,64}$ The leukocytosis is enriched for $\mathrm{CD} 34^{+}$cells and enrichment peaks approximately 6 to 9 hours after a single injection of plerixafor. ${ }^{65}$ The concentration of $\mathrm{CD} 34^{+}$cells correlates with increasing drug concentration from $40 \mu \mathrm{g} /$ $\mathrm{kg}$ to $240 \mu \mathrm{g} / \mathrm{kg}$. There is no change in other hematologic parameters such platelet or erythrocyte count. ${ }^{59}$ These trials demonstrated that plerixafor was safe and tolerable with only mild and transient toxicities, including injection site erythema, nausea, headache, dry mouth, and abdominal distension unrelated to dose.

The effect of plerixafor was also explored in combination with G-CSF, using a standard G-CSF dosing schedule, in healthy volunteers. The results demonstrated a synergistic effect between the two compounds leading to a 3.8 -fold increase in mobilization of $\mathrm{CD}^{+} 4^{+}$cells. The study also demonstrated that the combination of plerixafor and G-CSF is superior to either compound used in isolation and is generally safe and effective. ${ }^{65}$
Disease trials have yielded very promising results. A phase I trial in 13 patients with hematologic malignancies, $7 \mathrm{MM}$ and $6 \mathrm{NHL}$, demonstrated that either 160 or $240 \mu \mathrm{g} / \mathrm{kg}$ plerixafor is safe and can effectively mobilize HSPC without significant adverse events. ${ }^{66}$ The combination of G-CSF plus plerixafor was superior to G-CSF alone in MM (10 patients) and NHL (15 patients) ${ }^{67}$ A preliminary report of a five-patient Spanish experience also demonstrated similar results in patients with NHL and HD. ${ }^{68}$

\section{Phase II}

The efficacy of plerixafor in heavily pre-treated patient populations was examined in 49 patients who were enrolled in a single arm, multicenter Phase II study of plerixafor $(240 \mu \mathrm{g} / \mathrm{kg})$ with G-CSF in MM (26) and NHL (23) patients undergoing their first mobilization. The mobilization regimen consisted of G-CSF (10 $\mu \mathrm{g} / \mathrm{kg} /$ day) given for up to 9 days and plerixafor was started on day 4 and apheresis began on day 5. Fifty-seven percent of the patients were considered to be heavily pre-treated with 10 or more chemotherapy cycles. As a result, the heavily pre-treated patient cohort had similar mobilization characteristics as the non-heavily pretreated ones. The median CD34 $4^{+}$cells $/ \mathrm{kg}$ collected was $5.9 \times 10^{6}$ in 2 days of apheresis. Ninety-six percent of the patients enrolled were able to proceed to transplant. ${ }^{69}$

Another 25-patient phase II trial compared standard G-CSF-based apheresis to apheresis with G-CSF and plerixafor in patients with MM or NHL where each patient served as their internal control. The study demonstrated superior $\mathrm{CD} 34^{+}$collection and fewer apheresis procedures with the combined G-CSF and plerixafor regimen. ${ }^{67}$ The first European trial utilizing G-CSF and plerixafor in $31 \mathrm{MM}$ and 
4 NHL patients demonstrated similar results to the other phase II trials and confirmed that there was no additional tumor mobilization in the MM patients. ${ }^{70} \mathrm{~A}$ second phase II European trial with $13 \mathrm{MM}$ and 2 NHL patients analyzed lineage specific markers of G-CSF mobilizations and G-CSF plus plerixafor mobilization and repopulation potential in vitro and in vivo. Their data suggest that the addition of plerixafor to G-CSF mobilization may lead to the enhanced mobilization of a more primitive $\mathrm{CD} 34^{+}$cell population with high repopulation capacity. ${ }^{71}$

A phase II multicenter pilot study trial consisting of $26 \mathrm{MM}$ and 14 NHL patients addressed the issue of whether plerixafor can boost the PBSC mobilization associated with chemotherapy and G-CSF. The design included a first day apheresis procedure without plerixafor. Plerixafor was administered before the second apheresis procedure to allow the patients to serve as their own controls. The results suggested that the addition of plerixafor to chemotherapy and G-CSF was synergistic and resulted in a 2-fold increase in mobilized $\mathrm{CD} 4^{+}$cells. The mean rate of increase in the peripheral blood CD34 cells was 2.8 cells $/ \mu \mathrm{L} / \mathrm{h}$ pre- and 13.3 cells $/ \mu \mathrm{L} / \mathrm{h}$ postplerixafor administration. This was a heterogeneous population in which multiple chemotherapy regimens and disease states were included in the study patients. While the design was limited by the number of patients in an individual cohort, this study succeeded as a pilot and will serve as impetus to further investigate plerixafor as an adjunct to chemotherapy and G-CSF for PBSC mobilization. ${ }^{72}$ One interesting highlighted patient reported by the investigators was an individual who appeared to be in the process of failing CD $34^{+}$mobilization with chemotherapy and G-CSF and was successfully rescued with the addition of plerixafor.

To that purpose, plerixafor can also be effectively used in the salvage setting for patients who have previously failed mobilization with chemotherapy and/or G-CSF. A 20 patient institutional experience demonstrated that G-CSF and plerixafor can be used to effectively salvage patients of multiple diagnoses who had previously failed other mobilization attempts. The patients collected a median of $3.8 \times 10^{6} \mathrm{CD}^{2} 4^{+}$cells $/ \mathrm{kg}$ in 2 days of apheresis. 16 of 20 patients were capable of proceeding to auto-SCT and had neutrophil engraftment occurring around day 12 and platelet engraftment at approximately day $24 .{ }^{73}$ These results have been confirmed in a variety of other settings including a phase II trial of 20 patients with NHL and MM. ${ }^{74}$ That particular study also observed no evidence of tumor cell mobilization in the peripheral blood after plerixafor with G-CSF. The results were also consistent with the data obtained from the company sponsored final retrospective analysis of the safety data compiled from the 286 patients (164 NHL, 35 HD, 87 MM) who were enrolled in a compassionate use program in the United States. ${ }^{75-78}$ These results with 'poor mobilizers' have also been further reported in abstract form where $18 / 20$ patients, ${ }^{79} 16 / 17$ patients, ${ }^{80}$ $5 / 8$ patients, ${ }^{81} 5 / 6$ patients, ${ }^{82}$ and $2 / 4$ patients ${ }^{83}$ of varying diagnoses both in Europe and the United States were then capable of proceeding to transplant. Subpopulation analysis of these patients enrolled in the compassionate use trial also identified that peripheral blood progenitors from NHL patients pretreated with fludarabine can also still be safely and predictably mobilized with plerixafor and G-CSF. ${ }^{84,85}$

\section{Phase III}

There are two phase III multicenter, placebo controlled randomized trials of plerixafor + G-CSF versus placebo + G-CSF that enrolled NHL (trial \# 3101), and MM, (trial \# 3102) patients. A total of 298 NHL patients and 302 MM patients have been enrolled in these studies. The objective of the trials was to achieve a target number of $\mathrm{CD} 4^{+}$cells $/ \mathrm{kg}$ within a pre-specified number of apheresis days and having successful engraftment. The NHL primary endpoints were: 1 ) $\geq 2 \times 10^{6}$ cells $/ \mathrm{kg}$ in $\leq 4$ apheresis days and successful engraftment and 2) $\geq 5 \times 10^{6}$ cells $/ \mathrm{kg}$ in $\leq 4$ apheresis days and successful engraftment. The MM primary endpoints were: 1$) \geq 6 \times 10^{6}$ cells $/ \mathrm{kg}$ in $\leq 2$ apheresis days and successful engraftment. Engraftment was defined absolute neutrophil count $(\mathrm{ANC}) \geq 0.5 \times 10^{6} / \mathrm{L}$ for 3 days or $\geq 1.0 \times 10^{6} / \mathrm{L}$ for 1 day; and platelets $\geq 20 \times 10^{6} / \mathrm{L}$ for 7 days. Graft durability was defined as two of the following three: 1) platelets $\geq 50 \times 10^{6} / \mathrm{L}$ without transfusion for at least 2 weeks; 2) hemoglobin $\geq 10 \mathrm{~g} / \mathrm{dL}$ with no erythropoietin support or transfusions for at least 1 month; 3 ) ANC $>1 \times 10^{6} / \mathrm{L}$ with no G-CSF for at least 1 week. The interim analysis, 100 days, ${ }^{86,87}$ showed similar results to the 1 -year follow up. The NHL results demonstrated significantly increased numbers of $\mathrm{CD} 34^{+}$cells $/ \mathrm{kg}$ recovered for autologous transplant with plerixafor and G-CSF in comparison to G-CSF and placebo. Time to achieve $\geq 5 \times 10^{6}$ cells $/ \mathrm{kg}$ was also faster with plerixafor. $27.9 \%$ of NHL patients receiving plerixafor + G-CSF were able to reach this level within 1 day as compared to only $24.2 \%$ by day 4 with placebo + G-CSF. Additionally more patients proceeded directly to transplant in the plerixafor arm, 90\%, than placebo, $55.4 \% .{ }^{88}$ The MM trial showed similar significant improvement in $\mathrm{CD}^{+} 4^{+}$cells $/ \mathrm{kg}$ yield with the plerixafor arm. Of the plerixafor group, $71.6 \%$ had achieved $\geq 6 \times 10^{6} \mathrm{CD}^{+} 4^{+}$ 
cells $/ \mathrm{kg}$ in $\leq 2$ days while $34.4 \%$ of the placebo achieved the endpoint. ${ }^{89}$ As noted above in the lymphoma cohort, equivalent numbers of patients in the plerixafor group achieved the primary endpoint in 1 day as the placebo did in 4 days. In both studies, the autografts were found to be durable at 1 year after the ASCT procedure. ${ }^{88-91}$

\section{Secondary analysis}

The phase III trials have also been a source of very valuable information obtained in the post-hoc analysis. In the 3101 NHL study, 124 of the 298 patients were older than 60 years. In this elderly group, $50.9 \%$ of the patients receiving G-CSF and plerixafor met the primary endpoint compared to $25.4 \%$ of the patients receiving placebo. Similarly, 145 of the $302 \mathrm{MM}$ patients in 3102 were older than 60 years. Of patients receiving plerixafor $69.6 \%$ met the primary endpoint compared to $23.7 \%$ of the placebo group. The subpopulation analysis suggests that plerixafor plus G-CSF is superior than G-CSF in MM and NHL patients older than 60 years who are undergoing ASCT..$^{92,93}$ Another analysis using the data set from the phase III suggested that transplanted cell dose was associated with better long-term platelet recovery. ${ }^{94,95}$ Combining the MM patients from the phase III trial and the compassionate use trial also provides support to suggest that the majority of patients pretreated with lenalidomide can be successfully mobilized with plerixafor and G-CSF. ${ }^{96,97}$

Additional observations for the clinical use of plerixafor include the following series:

1. Three female MM patients received a reduced dose of $160 \mu \mathrm{g} / \mathrm{kg} /$ day following 4 days of G-CSF post-dialysism, suggesting that plerixafor could also be effectively used in $\mathrm{MM}$ patients on dialysis. ${ }^{98}$

2. An examination of 35 patients, $31 \mathrm{MM}$ and 4 NHL, suggested that plerixafor does not seem to contribute to tumor cell mobilization more than G-CSF alone. ${ }^{99,100}$

3. An analysis of 7 NHL patients who were mobilized with plerixafor plus G-CSF suggests that patients mobilized with plerixafor may actually experience improved clinical outcomes at 20 months, although it is recognized that this is a very small cohort analysis. ${ }^{101}$

Plerixafor is also undergoing assessment of efficacy in the allogeneic related donor setting as a single agent. Twenty-five HLA matched sibling donors were mobilized with $240 \mu \mathrm{g} / \mathrm{kg}$ plerixafor 4 hours prior to apheresis. Ninety-two percent of the donors collected $\geq 2 \times 10^{6} \mathrm{CD}^{+} 4^{+}$cells $/ \mathrm{kg}$ in $\leq 2$ apheresis. Two-thirds of the donors mobilized the target minimal number of $\mathrm{CD} 34^{+}$cells $/ \mathrm{kg}, \geq 2 \times 10^{6}$ cells $/ \mathrm{kg}$, in 1 apheresis. The remaining donors repeated the dose of plerixafor and apheresis after 1 day of rest, on day 3. After administration of the myleoablative conditioning regimen, 20 patients proceeded to transplant with a median of $2.9 \times 10^{6} \mathrm{CD} 34^{+}$cells $/ \mathrm{kg}$ of recipient body weight of the plerixafor mobilized stem cells. While the total $\mathrm{CD} 34^{+}$cells/kg was relatively low, ${ }^{102}$ neutrophil engraftment occurred on median day 10 and platelet engraftment on median day 12. Acute graft-versus-host disease grades 2 to 4 occurred in $35 \%$ of patients, which was similar to historical controls, with recognition that plerixafor can mobilize lymphoid populations in addition to $\mathrm{CD}^{+} 4^{+}$stem cells. After a median follow up of 277 days, 14 patients remain in remission and are transfusion independent. ${ }^{103}$

\section{Summary of current role of plerixafor in stem cell mobilization}

Plerixafor is being used in a wide variety of settings. It appears to be particularly useful in patients who have been heavily pretreated or as effective therapy for frontline salvage of poor PBSC mobilizers. In conjunction with G-CSF, plerixafor is successful in decreasing the number of apheresis days and therefore the associated additional risks and cost of more apheresis procedures. Patients taking plerixafor also report minimal side effects compared to the side effects of G-CSF.

However, the current general dosing strategy of 10 PM prior to the day of apheresis is not ideal for minimizing total costs and patient acceptability. This is due to the short stays that are required as part of the sub-cutaneous administration. Adopting a dosing strategy similar to the Devine et $\mathrm{al}^{103}$ of administration on the day of apheresis could thus lead to lower overall costs associated with the procedure. Anecdotally, some centers have chosen to exploit the prolonged duration of circulating CD $34^{+}$progenitors seen after plerixafor administration, and are administering plerixafor at the very end of a outpatient clinic day, with apheresis beginning approximately 14 hours later with some success. Further exploration is still needed for determining the optimal use of this agent. Investigations of administration as a single agent are needed as our studies addressing ways to maximize routes of administration. Further studies are needed to clarify the role of plerixafor during chemotherapy and growth factor induced stem cell mobilization. Additionally, it may be advantageous to consider dose alterations of G-CSF in conjunction with plerixafor to maximize $\mathrm{CD} 34^{+}$stem cell recovery. Other areas of further study include determining the role of plerixafor use in the pediatric setting, and also more detailed analysis of tumor cell mobilization. As previously stated, one 
study failed to demonstrate tumor cell mobilization in MM patients. ${ }^{74}$ However, because plerixafor has been shown to mobilize normal lymphoid cells into circulation, the possibility remains that lymphoma cells can be mobilized also. If recognized, perhaps these events can be explored, as is currently occurring with acute myeloid leukemia. ${ }^{104}$ Finally, it will be interesting to watch whether plerixafor will be the first in a series of agents to be used in humans which can exploit the chemokine axis. ${ }^{47}$

\section{Disclosures}

RTM has received a research grant from and has participated in advisory boards and is a speaker for Genzyme Inc. CJF has no disclosures.

\section{References}

1. Kondo M, Wagers AJ, Manz MG, et al. Biology of hematopoietic stem cells and progenitors: implications for clinical application. Ann Rev Immunol. 2003;21:759-806.

2. Körbling M, Anderlini P. Peripheral blood stem cell versus bone marrow allotransplantation: does the source of hematopoietic stem cells matter? Blood. 2001;98(10):2900-2908.

3. Beyer J, Schwella N, Zingsem J, et al. Hematopoietic rescue after high-dose chemotherapy using autologous peripheral-blood progenitor cells or bone marrow: a randomized comparison. J Clin Oncol. Jun 1995;13(6):1328-1335.

4. Hartmann O, Le Corroller AG, Blaise D, et al. Peripheral blood stem cell and bone marrow transplantation for solid tumors and lymphomas hematologic recovery and costs. A randomized, controlled trial. Ann Int Med. 1997;126(8):600-607.

5. Villalon L, Odriozola J, Larana JG, et al. Autologous peripheral blood progenitor cell transplantation with $<2 \times 10(6) \mathrm{CD} 34(+) / \mathrm{kg}$ : an analysis of variables concerning mobilisation and engraftment. Hematol $J$. 2000;1(6):374-381.

6. Allan DS, Keeney M, Howson-Jan K, et al. Number of viable CD34(+) cells reinfused predicts engraftment in autologous hematopoietic stem cell transplantation. Bone Marrow Transplantation. 2002;29(12): 967-972.

7. Gajewski JL, LeMaistre CF, Samuel MS, et al. Impending challenges in the hematopoietic stem cell transplantation physician workforce. Biol Blood Marrow Transplant. 2009;15:1493-1501.

8. Pasquini MC, Wang Z. Current use and outcome of hematopoietic stem cell transplantation: Part 1 - CIBMTR Summary Slides. CIBMTR Newsletter [serial online]. 2009:7-11. http://www.cibmtr. org/ReferenceCenter/Newsletters/PDF/Newsletter_Dec2009.pdf

9. Pasquini MC, He V, Perez WS. CIBMTR summary slides part 1. 2006:5-7. http://www.cibmtr.org/ReferenceCenter/Newsletters/PDF/ Newsletter_May2006.pdf

10. Hahn T, Wingard JR, Anderson KC, et al. The role of cytotoxic therapy with hematopoietic stem cell transplantation in the therapy of multiple myeloma: an evidence-based review. Biol Blood Marrow Transplant. 2003;9:4-37.

11. Giralt S, Stadtmauer EA, Harousseau JL, et al. International myeloma working group (IMWG) consensus statement and guidelines regarding the current status of stem cell collection and high-dose therapy for multiple myeloma and the role of plerixafor (AMD 3100). Leukemia. 2009;23:1904-1912.

12. Hahn T, Wolff SN, Czuczman M, et al. The role of cytotoxic therapy with hematopoietic stem cell transplantation in the therapy of diffuse large cell B-cell non-Hodgkin's lymphoma: an evidence-based review. Biol Blood Marrow Transplant. 2001;7:308-331.
13. Appelbaum FR. The current status of hematopoietic cell transplantation. Annu Rev Med. 2003;54:491-512.

14. Spitzer G, Adkins D, Mathews M, et al. Randomized comparison of G-CSF + GM-CSF vs G-CSF alone for mobilization of peripheral blood stem cells: effects on hematopoietic recovery after high-dose chemotherapy. Bone Marrow Transplant. 1997;20(11):921-930.

15. Narayanasami U, Kanteti R, Morelli J, et al. Randomized trial of filgrastim versus chemotherapy and filgrastim mobilization of hematopoietic progenitor cells for rescue in autologous transplantation. Blood. 2001;98(7):2059-2064.

16. Koenigsmann M, Jentsch-Ullrich K, Mohren M, et al. The role of diagnosis in patients failing peripheral blood progenitor cell mobilization. Transfusion. 2004:44(5):777-784.

17. Pelus LM, Singh P. The Combination of AMD 3100 Plus GRO $\{$ beta $\}$ Rapidly Mobilizes Hematopoietic Stem Cells with Enhanced Homing, Adhesion and Survival Properties. Blood. 2008;112(11):34 (Abstract 71).

18. Grigg AP, Roberts AW, Raunow H, et al. Optimizing dose and scheduling of filgrastim (granulocyte colony-stimulating factor) for mobilization and collection of peripheral blood progenitor cells in normal volunteers. Blood. 1995;86(12):4437-4445.

19. Roberts AW, DeLuca E, Begley CG, et al. Broad inter-individual variations in circulating progenitor cell numbers induced by granulocyte colony-stimulating factor therapy. Stem Cells. 1995;13(5):512-516.

20. Sugrue MW, Williams K, Pollock BH, et al. Characterization and outcome of "hard to mobilize" ' lymphoma patients undergoing autologous stem cell transplantation. Leuk Lymphoma. 2000;39(5-6):509-519.

21. Dreger P, Klöss M, Petersen B, et al. Autologous progenitor cell transplantation: prior exposure to stem cell-toxic drugs determines yield and engraftment of peripheral blood progenitor cell but not of bone marrow grafts. Blood. 1995;86(10):3970-3978.

22. Carral A, de la Rubia J, Martín G, et al. Factors influencing the collection of peripheral blood stem cells in patients with acute myeloblastic leukemia and non-myeloid malignancies. Leukemia Res. 2003;27(1):5-12.

23. Watts M, Linch D. The incidence of first mobilisation failure with chemotherapy and G-CSF in 594 patients with lymphoproliferative disease: potential for intervention with Plerixafor. Bone Marrow Transplant. 2009;43(S189):Abstract P705.

24. Pusic I, Jiang SY, Landua S, et al. Impact of mobilization and remobilization strategies on achieving sufficient stem cell yields for autologous transplantation. Biol Blood Marrow Transplant. 2008;14(9):1045-1056.

25. Kurzrock R. Thrombopoietic factors in chronic bone marrow failure states: the platelet problem revisited. Clin Cancer Res. 2005; 11(4):1361-1367.

26. Esté JA, Cabrera C, De Clercq E, et al. Activity of different bicyclam derivatives against human immunodeficiency virus depends on their interaction with the CXCR4 chemokine receptor. Mol Pharmacol. 1999;55(1):67-73.

27. Schols D, Struyf S, Van Damme J, et al. Inhibition of T-tropic HIV strains by selective antagonization of the chemokine receptor CXCR4. J Exp Med. 1997;186(8):1383-1388.

28. Broxmeyer HE, Hangoc G, Cooper S, et al. AMD3100 and CD26 modulate mobilization, engraftment, and survival of hematopoietic stem and progenitor cells mediated by the SDF-1/CXCL12-CXCR4 axis. Ann N Y Acad Sci. 2007;1106:1-19.

29. Hendrix CW, Collier AC, Lederman MM, et al. Safety, pharmacokinetics, and antiviral activity of AMD3100, a selective CXCR4 receptor inhibitor, in HIV-1 infection. J Acquir Immune Defic Syndr. 2004;37(2):1253-1262.

30. De Clercq E. The AMD3100 story: the path to the discovery of a stem cell mobilizer (Mozobil). Biochem Pharmacol. 2009;77(11):16551664.

31. Broxmeyer HE, Orschell CM, Clapp DW, et al. Rapid mobilization of murine and human hematopoietic stem and progenitor cells with AMD3100, a CXCR4 antagonist. The J Exp Med. 2005;201(8): $1307-1318$ 
32. Moser B, Wolf M, Walz A, Loetscher P. Chemokines: multiple levels of leukocyte migration control. Trends Immunol. 2004;25(2):75-84.

33. Sallusto F, Baggiolini M. Chemokines and leukocyte traffic. Nat Immunol. 2008;9(9):949-952.

34. Wright DE, Bowman EP, Wagers AJ, Butcher EC, Weissman IL. Hematopoietic stem cells are uniquely selective in their migratory response to chemokines. $J$ Exp Med. 2002;195(9):1145-1154.

35. Murdoch C. CXCR4: chemokine receptor extraordinaire. Immunol Rev. 2000;177:175-184.

36. Müller A, Homey B, Soto H, et al. Involvement of chemokine receptors in breast cancer metastasis. Nature. 2001;410(6824):50-56.

37. Laird DJ, von Andrian UH, Wagers AJ. Stem cell trafficking in tissue development, growth, and disease. Cell. 2008;132(4):612-630.

38. Zlotnik A. Involvement of chemokine receptors in organ-specific metastasis. Contrib Microbiol. 2006;13:191-199.

39. Honczarenko M, Douglas RS, Mathias C, et al. SDF-1 responsiveness does not correlate with CXCR4 expression levels of developing human bone marrow B cells. Blood. 1999;94(9):2990-2998.

40. Gupta SK, Pillarisetti K, Lysko PG. Modulation of CXCR4 expression and SDF-1alpha functional activity during differentiation of human monocytes and macrophages. J Leukoc Biol. 1999;66(1):135-143.

41. Martin C, Burdon PCE, Bridger G, et al. Chemokines acting via CXCR2 and CXCR4 control the release of neutrophils from the bone marrow and their return following senescence. Immunity. 2003;19(4):583-593.

42. Kollet O, Spiegel A, Peled A, et al. Rapid and efficient homing of human CD34(+)CD38(-/low)CXCR4(+) stem and progenitor cells to the bone marrow and spleen of NOD/SCID and NOD/SCID/B2m(null) mice. Blood. 2001;97(10):3283-3291.

43. Sipkins DA, Wei $\mathrm{X}, \mathrm{Wu} \mathrm{JW}$, et al. In vivo imaging of specialized bone marrow endothelial microdomains for tumour engraftment. Nature. 2005;435(7044):969-973.

44. Burger JA, Kipps TJ. CXCR4: a key receptor in the crosstalk between tumor cells and their microenvironment. Blood. 2006;107(5): $1761-1767$.

45. Wang J, Loberg R, Taichman RS. The pivotal role of CXCL12 (SDF-1)/ CXCR4 axis in bone metastasis. Cancer Metastasis Rev. 2006; 25(4):573-587.

46. Rettig M, Devine SM, Ritchey J, DiPersio JF. Phenotypic and functional analysis of T-cells mobilized in hla-matched sibling donors following treatment with the chemokine antagonist AMD3100. ASH Blood. 2006;108(11):3001.

47. Burger JA, Peled A. CXCR4 antagonists: targeting the microenvironment in leukemia and other cancers. Leukemia. 2009;23(1):43-52.

48. Lack NA, Green B, Dale DC, et al. A pharmacokinetic-pharmacodynamic model for the mobilization of CD34+ hematopoietic progenitor cells by AMD3100. Clin Pharmacol Ther. 2005;77(5):427-436.

49. Hendrix CW, Flexner C, MacFarland RT, et al. Pharmacokinetics and safety of AMD-3100, a novel antagonist of the CXCR-4 chemokine receptor, in human volunteers. Antimicrob Agents Chemother. 2000;44(6): 1667-1673

50. Hatse S, Princen K, Bridger G, De Clercq E, Schols D. Chemokine receptor inhibition by AMD3100 is strictly confined to CXCR4. FEBS Letters. 2002;527(1-3):255-262.

51. Levoye A, Balabanian K, Baleux F, Bachelerie F, Lagane B. CXCR7 heterodimerizes with CXCR4 and regulates CXCL12-mediated G protein signaling. Blood. 2009;113(24):6085-6093.

52. Gupta SK, Lysko PG, Pillarisetti K, Ohlstein E, Stadel JM. Chemokine receptors in human endothelial cells. Functional expression of CXCR4 and its transcriptional regulation by inflammatory cytokines. $J$ Biol Chem. 1998;273(7):4282-4287.

53. Murdoch C, Monk PN, Finn A. Cxc chemokine receptor expression on human endothelial cells. Cytokine. 1999;11(9):704-712.

54. Fricker SP, Anastassov V, Cox J, et al. Characterization of the molecular pharmacology of AMD3100: a specific antagonist of the G-protein coupled chemokine receptor, CXCR4. Bioch Pharmacol. 2006;72(5):588-596.
55. Plerixafor. 2010. http://www.accessdata.fda.gov.

56. Burger M, Hartmann T, Krome M, et al. Small peptide inhibitors of the CXCR4 chemokine receptor (CD184) antagonize the activation, migration, and antiapoptotic responses of CXCL12 in chronic lymphocytic leukemia B cells. Blood. 2005 Sep 1;106(5):1824-1830.

57. Nervi B, Holt M, Rettig MP, et al. AMD3100 mobilizes acute promyelocytic leukemia cells from the bone marrow into the peripheral blood and sensitizes leukemia cells to chemotherapy. Blood. 2005;106(11):246.

58. Balaguer H, Galmes A, Ventayol G, Bargay J, Besalduch J. Splenic rupture after granulocyte-colony-stimulating factor mobilization in a peripheral blood progenitor cell donor. Transfusion. 2004;44(8):1260-1261.

59. Hübel K, Liles WC, Broxmeyer HE, et al. Leukocytosis and mobilization of CD34+ hematopoietic progenitor cells by AMD3100, a CXCR4 antagonist. Support Cancer Ther. 2004;1(3):165-172.

60. Broxmeyer HE, Mejia JAH, Hangoc G, et al. SDF-1/CXCL12 enhances in vitro replating capacity of murine and human multipotential and macrophage progenitor cells. Stem Cells Dev. 2007;16(4):589-596.

61. Burroughs L, Mielcarek M, Little MT, et al. Durable engraftment of AMD3100-mobilized autologous and allogeneic peripheralblood mononuclear cells in a canine transplantation model. Blood. 2005;106(12):4002-4008.

62. Larochelle A, Krouse A, Metzger M, et al. AMD3100 mobilizes hematopoietic stem cells with long-term repopulating capacity in nonhuman primates. Blood. 2006;107(9):3772-3778.

63. Donahue RE, Jin P, Bonifacino AC, et al. Plerixafor (AMD3100) and granulocyte colony stimulating factor (G-CSF) mobilize different CD34+ cell populations based on global gene and microRNA expression signatures. Blood. 2009;114:2530-2541.

64. Liles WC, Broxmeyer HE, Rodger E, et al. Mobilization of hematopoietic progenitor cells in healthy volunteers by AMD3100, a CXC R4 antagonist. Blood. 2003;102:2728-2730.

65. Liles WC, Rodger E, Broxmeyer HE, et al. Augmented mobilization and collection of CD34+ hematopoietic cells from normal human volunteers stimulated with granulocyte-colony-stimulating factor by single-dose administration of AMD3100, a CXCR4 antagonist. Transfusion. 2005;45(3):295-300.

66. Devine SM, Flomenberg N, Vesole DH, et al. Rapid mobilization of CD34+ cells following administration of the CXCR4 antagonist AMD3100 to patients with multiple myeloma and non-Hodgkin's lymphoma. J Clin Oncol. 2004;22(6):1095-1102.

67. Flomenberg N, Devine SM, Dipersio JF, et al. The use of AMD3100 plus G-CSF for autologous hematopoietic progenitor cell mobilization is superior to G-CSF alone. Blood. 2005;106(5):1867-1874.

68. Ortiz M, Contento A, Galera P, et al. Effective peripheral blood progenitor cell mobilization with G-CSF and plerixafor: A promising mobilization treatment? European Hematology Association. 2009;14th Congress:Abstract 1176.

69. Stiff P, Micallef I, McCarthy P, et al. Treatment with plerixafor in nonHodgkin's lymphoma and multiple myeloma patients to increase the number of peripheral blood stem cells when given a mobilizing regimen of G-CSF: implications for the heavily pretreated patient. Biol Blood Marrow Transplant. 2009;15(2):249-256.

70. Fruehauf S, Ehninger G, Hubel K, et al. Mobilization of peripheral blood stem cells for autologous transplant in non-Hodgkin's lymphoma and multiple myeloma patients by plerixafor and G-CSF and detection of tumor cell mobilization by PCR in multiple myeloma patients. Bone Marrow Transplant. 2009;45(2):269-275.

71. Fruehauf S, Veldwijk MR, Seeger T, et al. A combination of granulocyte-colony-stimulating factor (G-CSF) and plerixafor AMD3100 (plerixafor) mobilizes more primitive peripheral blood progenitor cells than G-CSF alone: results of a European phase II study. Cytotherapy. 2009:1-10.

72. Dugan MJ, Maziarz RT, Bensinger WI, et al. Safety and preliminary efficacy of plerixafor (Mozobil) in combination with chemotherapy and G-CSF: an open-label, multicenter, exploratory trial in patients with multiple myeloma and non-Hodgkin's lymphoma undergoing stem cell mobilization. Bone Marrow Transplant. 2009;45:39-47. 
73. Fowler CJ, Dunn A, Hayes-Lattin B, et al. Rescue from failed growth factor and/or chemotherapy HSC mobilization with G-CSF and plerixafor (AMD3100): an institutional experience. Bone Marrow Transplant. 2009;43:909-917.

74. Tricot G, Cottler-Fox MH, Calandra G. Safety and efficacy assessment of plerixafor in patients with multiple myeloma proven or predicted to be poor mobilizers, including assessment of tumor cell mobilization. Bone Marrow Transplant. 2009;45(1):63-68.

75. Shaughnessy P, McSweeney P, Solomon S, et al. Effect of plerixafor plus G-CSF among patients who failed to collect sufficient hematopoietic stem cells after mobilization attempt with chemotherapy plus cytokines. 35th Annual EBMT Meeting. Goteborg, Sweden 2009.

76. Shaughnessy P, McSweeney P, Solomon S, et al. Effect of plerixafor plus G-CSF among patients who failed to collect sufficient hematopoietic stem cells after mobilization attempt with chemotherapy plus cytokines. Bone Marrow Transplant. 2009;43(S108):Abstract P493.

77. Micallef I, Stiff PJ, DiPersio JF, et al. Successful stem cell mobilization rescue by AMD3100 (Plerixafor) + G-CSF for patients who failed primary mobilization: Results from the phase III (3101-NHL) study. Blood. 2007;110(11):602.

78. Calandra G, McCarty J, McGuirk J, et al. AMD3100 plus G-CSF can successfully mobilize CD34+ cells from non-Hodgkin's lymphoma, Hodgkin's disease and multiple myeloma patients previously failing mobilization with chemotherapy and/or cytokine treatment: compassionate use data. Bone Marrow Transplant. 2008;41(4): 331-338.

79. Duarte R, Marin P, Ortiz M, et al. Plerixafor plus G-CSF can successfully mobilise CD34+ cells from patients with lymphoid malignancies who have previously failed chemotherapy and/or cytokine mobilisation compassionate use experience in Spain. Bone Marrow Transplant. 2009;43(S80):Abstract O421.

80. Gordon WC, Johnson PRE, Roddie PH, et al. Plerixafor is highly effective in the mobilisation of PBSC for autlogous transplantation from patients failing to mobilise by conventional means: the initial Scottish experience in three transplant centres. Bone Marrow Transplant. 2009;43(S113):Abstract P504.

81. Worel N, Pribitzer B, Kasparu H, et al. Improved mobilisation of peripheral blood CD34+ cells by AMD3100 plus granulocyte-colonystimulating factor in hard to mobilize patients. Bone Marrow Transplant. 2009;43(S364-65):Abstract R1223.

82. Marturano E, Mauro E, Leotta S, et al. Plerixafor is able to mobilize a high proportion of Lymphoma and Myeloma patients that previously failed a PBSC mobilization: A single center study. European Hematology Association. 2009; 14th Congress:Abstract 1178.

83. Ostuni A, Pavone V, Caputo M, et al. AMD3100 in poor mobilizer patients with hematologic malignancies. European Hematology Association. 2009;14th Congress:Abstract 1177.

84. Schriber J, McCarty J, McGuirk J, et al. Plerixafor can predictable mobilize hematopoietic stem cells in patients with non-Hodgkin's lymphoma previously treated with fludarabine and undergoing autologous stem cell transplantation. 35th Annual EBMT Meeting. Berlin, Germany 2009.

85. Schriber J, McCarty J, McGuirk J, et al. Plerixafor can predict mobilize hematopoietic stem cells in patients with non-Hodgkin's lymphoma previously treated with fludarabine and undergoing autologous stem cell transplantation. European Hematology Association. 2009; 14th Congress:Abstract 0710

86. DiPersio J, Stadtmauer EA, Nademanee AP, et al. A phase III, multicenter, randomized, double-blind, placebo-controlled, comparative trial of AMD3100 (Plerixafor) + G-CSF vs G-CSF + placebo for mobilization in multiple myeloma (MM) patients for autologous hematopoietic stem cell (aHSC) transplantation. Blood. 2007;110(11):445.

87. DiPersio JF, Micallef I, Stiff PJ, et al. A phase III, multicenter, randomized, double-blind, placebo controlled, comparative trial of AMD3100 (Plerixafor) + G-CSF vs Placebo + G-CSF in NonHodgkin's Lymphoma (NHL) patients for autologous hematopoietic stem cell (aHSC) Transplantation. Blood. 2007;110(11):601.
88. DiPersio JF, Micallef IN, Stiff PJ, et al. Phase III prospective randomized double-blind placebo-controlled trial of plerixafor plus granulocyte colony-stimulating factor compared with placebo plus granulocyte colony-stimulating factor for autologous stem-cell mobilization and transplantation for patients with non-Hodgkin's lymphoma. J Clin Oncol. 2009;27(28):4767-4773.

89. DiPersio JF, Stadtmauer EA, Nademanee A, et al. Plerixafor and G-CSF versus placebo and G-CSF to mobilize hematopoietic stem cells for autologous stem cell transplantation in patients with multiple myeloma. Blood. 2009;113(23):5720-5726.

90. DiPersio JF, Micallef INM, Nademanee A, et al. Results of two phase III, multicentre, randomised, placebo-controlled trials of plerixafor $+\mathrm{G}-\mathrm{CSF}$ versus G-CSF + placebo for mobilisation and engraftment of non-Hodgkin's lymphoma and multiple myeloma patiens undergoing autologous transplantation. EBMT. 2009;43:Poster P482.

91. DiPersio JF, Micallef INM, Nademanee A, et al. Results of two phase III, multicentre, randomised, placebo-controlled trials of plerixafor $+\mathrm{G}-\mathrm{CSF}$ versus G-CSF + placebo for mobilisation and engraftment of nonHodgkin's lymphoma and multiple myeloma patiens undergoing autologous transplantation. Bone Marrow Transplant. 2009;43(S104):Poster.

92. Micallef INM, DiPersio JF, Nademanee A, et al. Efficacy of plerixafor plus G-CSF compared to G-CSF plus placebo for mobilisation of CD34+ haematopoietic progenitor cells in pateints older than 60 years with non-Hodgkin's lymphoma or multiple myeloma. Bone Marrow Transplant. 2009;43(S105):Abstract P485.

93. Micallef INM, DiPersio JF, Nademanee A, et al. Safety and efficacy of plerixafor plus G-CSF compared to G-CSF plus placebo for mobilisation of CD34+ haematopoietic progenitor cells in pateints older than 60 years with non-Hodgkin's lymphoma or multiple myeloma. 35th Annual EBMT Meeting. Goteborg, Sweden 2009.

94. Stiff PJ, Micallef INM, Nademanee A, et al. Transplanted CD34+ cell dose is associated with long-term platelet count recovery following autologous haematopoietic stem cell transplant in patients with non-Hodgkin's lymphoma and multiple myeloma. Bone Marrow Transplant. 2009;43(S114):Abstract 506.

95. Stiff PJ, Micallef INM, Nademanee A, et al. Transplanted CD34+ cell dose is associated with long-term platelet count recovery following autologous haematopoietic stem cell transplant in patients with nonHodgkin's lymphoma and multiple myeloma. 35th Annual EBMT Meeting. Goteborg, Sweden 2009.

96. Micallef INM, Tarantolo S, McSweeney P, et al. Plerixafor can predictably mobilize hematopoietic stem cells in patients with multiple myeloma previously treated with lenalidomide. European Hematology Association. 2009; 14th Congress:Abstract 0718.

97. Micallef INM, Tarantolo S, McSweeney P, et al. Plerixafor can predictably mobilize hematopoietic stem cells in patients with multiple myeloma previously treated with lenalidomide. European Hematology Association: 14th Congress. Berlin, Germany 2009.

98. Douglas K, Hayden PJ, O’Dwyer ME, Rahemtulla A. Plerixafor plus G-CSF is effectinve withough significant toxicity in PBSC mobilisation from myeloma patients with dialysis-dependent renal failure who have failed to mobilise by conventional means: an initial series of three patients. Bone Marrow Transplant. 2009;43(S150):Abstract P600.

99. Fruehauf S, Topaly J, Muller S, et al. Effect of plerixafor plus G-CSF on tumour cell mobilisation in patients with multiple myeloma. Bone Marrow Transplant. 2009;43(S146):Abstract P589.

100. Fruehauf S, Topaly J, Muller S, et al. Effect of plerixafor plus G-CSF on tumour cell mobilisation in patients with multiple myeloma. 35 th Annual EBMT Meeting. Goteborg, Sweden 2009.

101. Holtan SG, Porrata LF, Micallef INM, et al. AMD3100 affects autograft lymphocyte collection and progression-free survival after autologous stem cell transplantation in non-Hodgkin lymphoma. Clinic Lymphoma Myeloma. 2007;7(4):315-318.

102. Pulsipher MA, Chitphakdithai P, Logan BR, et al. Donor, recipient, and transplant characteristics as risk factors after unrelated donor PBSC transplantation: beneficial effects of higher CD34+ cell dose. Blood. 2009;114(13):2606-2616. 
103. Devine SM, Vij R, Rettig M, et al. Rapid mobilization of functional donor hematopoietic cells without G-CSF using AMD3100, an antagonist of the CXCR4/SDF-1 interaction. Blood. 2008;112(4):990-998.
104. Nervi B, Ramirez P, Rettig MP, et al. Chemosensitization of acute myeloid leukemia (AML) following mobilization by the CXCR4 antagonist AMD3100. Blood. 2009;113(24):6206-6214.

\section{Publish your work in this journal}

Transplant Research and Risk Management is an international, peerreviewed open access journal focusing on all aspects of transplantation and risk management to achieve optimal outcomes in the recipient improving survival and quality of life. The journal welcomes submitted papers covering original research, basic science, clinical studies, reviews \& evaluations, guidelines, expert opinion and commentary, case reports and extended reports. The manuscript management system is completely online and includes a very quick and fair peer-review system, which is all easy to use. Visit http://www.dovepress.com/ testimonials.php to read real quotes from published authors. 